\section{Martian or Mauritanian? The Lesser-Known Human Security Crises in the Sahel}

\author{
Amanda Morrison \\ Sophomore, Global Studies/Strategic \\ Communication
}

While humanitarian crises have plagued the continent of Africa for years, some of the world's most severe and dire human security issues exist within the Sahel region. This geographic and geopolitical region in the middle of Africa is located between the Sahara and Savanna. The Sahel struggles with damaging security issues as well as economic and cultural problems. This region is representative of a security complex because Sahelian states' security is so interlinked that national security problems will never be solved apart from other Sahelian nations. While African nations such as Mali, Nigeria, and Chad are included in the Sahel region, a lesser-known and rarely discussed country is Mauritania. For a time being, Mauritania was so publically unrecognizable that autocorrect on smart phones would change "Mauritania" to "Martian" (Nashashibi 2012). Mauritania is unique because although it is situated near the violent nation Mali, it holds a mainly cooperative relationship with Western allies against Islamist insurgencies. This position highlights the country's importance and the need for stabilization. While numerous security problems pose a significant threat to Mauritanian stability, a concerted international effort to provide food, environmental, and political resources to the country can resolve these crises.
It is impossible to fully evaluate the security issues in Mauritania without first understanding the country's complicated history and deep security issues. In 1904, France established Mauritania as one of its colonial territories. Mauritania was completely dependent on French rule for political, economic, and social support during this time. With reforms to the French colonial system after the Second World War, Mauritania gained its independence in 1960. Mauritania's first president, Moktar Ould Daddah, ushered in an era of government corruption and authoritarian rule until he was overthrown by a coup in 1978 . After the coup, Mauritanians were under military rule until 2007, when the nation held its first democratic election since its independence (Stewart 2008). Furthermore, its sub-Saharan and Sahelian location in the desert presents infrastructure challenges that complicate travel and development; not to mention the long-standing problems with human slavery. The French practiced slavery under their colonial rule, and even though the practice was banned in 1981, its use in independent Mauritania is still widespread (Stewart 2008).

Mauritania faces humanitarian and domestic crises including, but not limited to, human slavery, environmental degradation, an influx of refugees, food insecurity, and development challenges. Since all of these concerns affect people in different ways, there are many potential ways to classify this security crisis. Although there are problems with labeling crises as "human security" issues, this is the best term to use for these overlapping crises. Human security allows all of the issues facing Mauritania to be grouped under one umbrella. Thus, human security is not merely a player in this crisis but it is the entire game. 
The response to these crises, however, needs to be carefully calculated to ensure aid and resources are allocated towards individual security efforts to best address the wide array of security concerns.

Although the international community should discuss the needed responses for these problems, it is first important to understand that there are unchangeable geographic factors that define the Sahel region, such as its desert landscape and hot climate. Countries in the Sahel will always have hardships because of their location, but Mauritania is distinct because of its numerous interconnected security issues. Furthermore, the end of French colonization in 1960 left Mauritania with little infrastructure to grow their government and establish a stable state, as ninety percent of their population was still nomadic at the time of independence. While it is twice as big in geographic size as the country of France, to this day it still only has around 500 miles of paved roads (Mauritania 2006). This is significant because Mauritania is "a territory of 398,000 square miles" and lacks critical infrastructure because of its desert setting (Sterling 1974).

While the pervasive security issues in Mauritania span multiple problem areas, examining these problems individually is key to understanding the needed policy and humanitarian responses. More recent issues such as the influx of Malian refugees have brought proximate causes of instability to the surface, but one deep cause of insecurity is Mauritania's long history of human slavery. Government corruption allowed the existence of slavery even after it was "banned" in the late twentieth century. Only one slave owner has successfully been tried and convicted to date. Mauritania has the highest percentage of an enslaved population in the world, and thus one of the most crucial human security concerns, with around ten to twenty percent of its 4.46 million citizens enslaved (Nossiter 2013). Not only are they still striving to abolish slavery in their society, but they are also wrestling with environmental security problems. Mauritania joins the ranks of dozens of developing countries that emit little to no carbon dioxide or other harmful emissions, but are still experiencing drastic effects from the Earth's warming. One such consequence is the flooding of its capital city, Nouakchott. So much rain fell in August and September of 2013 that 2,000 people were left homeless. Water was even up to seventy centimeters - or 2.3 feet - in some homes (Smith 2016). Other deep-seated issues such as urbanization and urban sprawl further this proximate cause of environmental insecurity. Urbanization is a deep cause of instability because the country's growing population increasingly flocked to city centers since the state's independence in the 1960s (Smith 2016). A recent census noted that the urban population grew from just four percent in 1962 to forty-eight percent-over one million people - in 2013 (Mauritania 2016). This drastic urban population increase means already scarce resources are now even scarcer in the city centers.

Unfortunately, human slavery and environmental insecurity are not the only security issues plaguing this West African nation. The proliferation of refugee crises across the globe also found its way to Mauritania. Since Mauritania shares a border with Mali, it is locked in a human security complex with them. Mali is one of the world's least developed countries, and colonialism and government corruption are deep causes of instability that stem from its similar independence from France in 1960. These 
continued problems caused instability to run rampant in Mali since its independence (Guterres 2012). The issues of food insecurity and an Islamic insurgency in Mali caused 42,000 people to recently pour across the border and establish new lives in the Mbera refugee camp in Mauritania (Smith 2016). Thus, not only are Mauritanians dealing with their own human security crises, but they are also trying to deal with their problems alongside the crises of tens of thousands of others. This poses a significant challenge of how to address all of these different security issues, not to mention the lack of food stability in the region. An estimated 239 million people are suffering from hunger in sub-Saharan Africa (Sasson 2012). One important component of food insecurity is that while many people go hungry in countries such as Mauritania, the larger problem is malnutrition. Malnutrition threatens the human security of twelve percent of children in Mauritania because citizens are often not able to access the nutrients they need (Kristof 2011). For example, "when people die of hunger-related causes, the problem is often not so much a lack of calories as a lack of micronutrients like iron and zinc" (Kristof 2011). The food insecurity and malnutrition problem is furthered by a lack of development; the lack of critical infrastructure makes it hard to get food to the people who need it most (Mauritania 2006). The deep problem of urbanization, coupled with the desert atmosphere in the Sahel and food security concerns, makes it hard for the international community to resolve these problems.

Many efforts, however, are already underway from a variety of actors to better the lives of Mauritanian citizens as well as refugees within the country. One such measure is the increase in water sanitation projects to combat flooding in Mauritania's capital city. This measure was introduced by the Mauritanian people themselves and is set to "be operational within three and a half years" as they put water pumps in place with double the capacity than before (Smith 2016). This Mauritanian-based environmental solution sets the example for how other countries should react to environmental security concerns in developing African nations. They turned to their own citizens to help create a sustainable solution to the flooding and this solution is already solving the problem. Another strong in-country response to insecurity comes from non-governmental organizations working at the Mbera refugee camp. Here, organizations spend ample time working with refugees in the 11,327 shelters in the camp to promote stability and discourage adherence to Islamic extremism in the region (Smith 2016). This political assistance could greatly improve security from terrorism in the region, and only time will tell how successful this refugee education becomes.

Western aid also played a key role in stabilizing one aspect of food insecurity in Mauritania. A flour mill in the country began adding essential vitamins and minerals to their food production in order to combat malnutrition. The New York Times writer Kristof noted, "American foreign aid money helped pay the startup cost of fortification, and the mill will pay all continuing costs. We watched the machines add tiny quantities of the nutrients to sacks of flour - and realized that this mill might end up saving more lives than a hospital" (Kristof 2011).

This aid project has the potential to create a sustainable, lasting impact on communities in Mauritania. Labor unions in the United States also encouraged the President to 
cut off duty-free trade with Mauritania just two months ago due to its failure to combat the human slavery crisis. Since Mauritania received a poor ranking on human rights from the United Nations earlier this year, the U.S. labor unions suggested the government take a hardline policy approach to affect the Sahelian nation economically (Ratcliffe 2017). Time will determine whether or not the U.S. is able to influence this Sahelian nation's policy with economic threats.

The diverse security concerns in Mauritania culminate under the umbrella of human security. The deep causes of insecurity in this Sahelian nation stem from French colonialism, government corruption, its geographic location in the Sahel, urbanization, and human slavery. Proximate causes include environmental degradation, an influx of Malian refugees, food insecurity and malnutrition, and development challenges. Thankfully, Mauritanian citizens, non-governmental organizations, and Western nations have all stepped up to bring resources and needed change to this country. These entities must remember, however, that simply giving aid money is not a sufficient response to fix all of the individual problems. From humanitarian aid to economic policies, concerted responses in the areas of food, environmental, and political resources not only better the lives of Mauritanians, but also place the Sahelian country on a firmer foundation. It is imperative that the international community supports individualized development efforts to stabilize Mauritania because these efforts will benefit the security interests of the world as a whole.

\section{References}

Guterres, Antonio. "Why Mali Matters." The New York Times. Sep. 4, 2012. http://www.nytimes.com/2012/09/05/opinion/w hy-mali-matters.html (accessed Oct. 4, 2017).

Kristof, Nicholas. "An African Adventure, and a Revelation." The New York Times. July 1, 2011.

http://www.nytimes.com/2011/07/03/opinion/s unday/03kristof.html (accessed Oct. 4, 2017).

"Mauritania." African Economic Outlook. 2016.

file://Users/bookwormbeth417/Downloads/M

AURITANIA\%20GB\%202016\%20

WEB.theme.pdf (accessed Oct. 29, 2017).

"Mauritania at a Glance." The Washington Post. Aug. 13, 2006.

https://www.washingtonpost.com/archive/politi cs/2006/08/13/mauritania-at-a-

glance/cee7230f-e998-4039-b0ae-3983afaf9afc /?utm_term=.e01975c38274 (accessed Oct. 4, 2017).

Nashashibi, Sharif. "Mauritania's 'Overlooked' Arab Spring." The Guardian. May 26, 2012.

https://www.theguardian.com/commentisfree/2 012/may/26/mauritania-

overlooked-arab-spring (accessed Oct. 4, 2017).

Nossiter, Adam. "Mauritania Confronts Long Legacy of Slavery." The New York Times.

Nov. 11, 2013.

http://www.nytimes.com/2013/11/12/world/afri $\mathrm{ca} /$ mauritania-confronts-long-

legacy-of-slavery.html (accessed Oct. 4, 2017).

Pitman, Todd. "Mauritania Junta's Promise of Democracy in Doubt." The Washington Post. Aug. 9, 2008.

http://www.washingtonpost.com/wp- 
dyn/content/article/2008/08/09/AR2008080901

$344 \_$f.html (accessed Oct. 4, 2017).

Ratcliffe, Rebecca. "US Warned Mauritania's

'Total Failure' on Slavery Should Rule Out

Trade Benefits." The Guardian. Aug. 25, 2017.

https://www.theguardian.com/global-developm ent/2017/aug/25/us-warned-

mauritania-total-failure-slavery-trade-benefits

(accessed Oct. 4, 2017).

Sasson, Albert. "Food Security for Africa: An Urgent Global Challenge." BioMed Central. Apr. 19, 2012.

https://agricultureandfoodsecurity.biomedcentr al.com/articles/10.1186/2048-7010-1-2

(accessed Oct. 28, 2017).

Smith, Alex Duval. "Malian Refugees in Mauritania, and India's All-woman

Newspaper." The Guardian. Aug. 23, 2016.

https://www.theguardian.com/globaldevelopment/2016/aug/23/malian-refugeesin-mauritania-and-indias-all-womannewspaper (accessed Oct. 4, 2017).

Smith, Alex Duval. "'The Best Solution? Move the Mauritanian Capital': Water on the Rise in Nouakchott." The Guardian. July 25, 2016.

https://www.theguardian.com/global-developm ent/2016/jul/25/the-best-solution-

move-the-mauritanian-capital-water-on-the-rise -in-nouakchott (accessed Oct. 4, 2017).

Sterling, Claire. "The Making of the

Sub-Saharan Wasteland." The Atlantic. May 1, 1974.

https://www.theatlantic.com/magazine/archive/ 1974/05/the-making-of-the-sub-saharan-wastel and/482175/ (accessed Oct. 4, 2017).

Stewart, Elizabeth. "History of Mauritania."

The Guardian. Aug. 6, 2008. https://www.theguardian.com/world/2008/aug/ 06/mauritania.history (accessed Oct. 29, 2017). 